\title{
Using mathematical programming method to optimize amount of injection gas for Dai Hung field, Nam Con Son basin, offshore Vietnam
}

- Phung Dai Khanh

- Le Thanh Liem

- Hoang Trong Quang

University of Technology, VNU-HCM

(Manuscript Received on August 25 $5^{\text {th }}$, 2014; Manuscript Revised November 11 $1^{\text {th }}$, 2014)

\section{ABSTRACT:}

During oil - production by gaslift method, because of the limitation of injection gas rate, the optimization of distributing injection gas rate for group of well is universally interesting. There are some optimization methods for gaslift well in Vietnam, nearly all uses analytical mathematic

Keywords: mathematical programming, optimization, gaslift, injection gas.

\section{INTRODUCTION}

Optimization, as a branch of mathematics, has many applications and widely effective. Therefore, the field of optimization is becoming increasingly diverse, with many different names such as Mathematics Programming, Optimal Control, Operation Research, Games Theory...

In mathematics, term optimization refers to the study of problems:

Given a function $f: A \rightarrow R$, find an element $x o \in A$ such that $f(x o) \leq f(x), \forall x \in A$ or $f(x o) \geq f(x) \forall x \in A$.

One such material formulation is sometimes called a mathematical programming. Many practical problems and theoretical model can be generalized in that way.

The domain A of f is called the search space. Typically, $A$ is a subset of Euclidean space $R^{n}$, usually defined by a set of constraints that the elements of A must satisfy. The elements of A are called the candidate solutions. The function $f$ is called an objective function. A feasible solution that minimizes or maximizes the objective function is called an optimal solution. method with solutions finding the extrema for multivariable function. This paper presents an optimization method for group of gaslift well to increase the oil rate for Dai Hung field, Nam Con Son Basin, offshore Vietnam.

To apply to design optimal regime for exploitation of gas-lift system, we will seek objective function based on production and injection gas data of each well satisfy constraints and find value to achieve the objective function value optimal.

\section{THEORETICAL BASIS}

2.1 Methods of analysis and research

Optimizing gas-lift production has many different definitions, but the general approach is to make the highest profit factor. Thus, the goal of optimization is to exploit the maximum flow, the minimum individual cost and maximum profit. In this paper based on criteria optimal maximum flow and minimum operators own expense. Optimizing group of gas-lift well will clear the following practical problem:

+ Group wells for maximum flow rate while excluding limited amounts of injection gas.

+ Distribution of injection gas to group of gas-lift wells for maximum flow rate for a given amount of injection gas.

\section{Trang 166}


On each operation curve $\mathrm{Q}=\mathrm{f}(\mathrm{V})$ has a feature called optimal flow-rate point, corresponding to the highest effective factor of gas-lift process, $\eta$.

The factor $\eta$ will reach a maximum value at the point where the ratio $(\mathrm{Q} / \mathrm{V})$ peak. Also, at tangent point to curve $\mathrm{Q}(\mathrm{V})$ drawn from the origin of axis. In this mode, the ratio $(\mathrm{V} / \mathrm{Q})$ is minimal, or the minimum amount of injection gas to raise a unit volume of fluid. The production rate corresponding to the maximum value of $\eta$ is called optimal rate.

The more volume of injection gas, the more production rate we have because of the decrease of fluid density in tubing. But, this only increased to $\mathrm{Q}_{\max }$ value, after that if volume of injection gas continues increasing the production rate will reduce because of slipping between injection gas and oil.

Therefore, the operation mode of the wells located between optimal mode $\left(\mathrm{Q}_{\text {opt }}\right)$ and maximum mode $\left(\mathrm{Q}_{\max }\right)$ (Fig. 1)

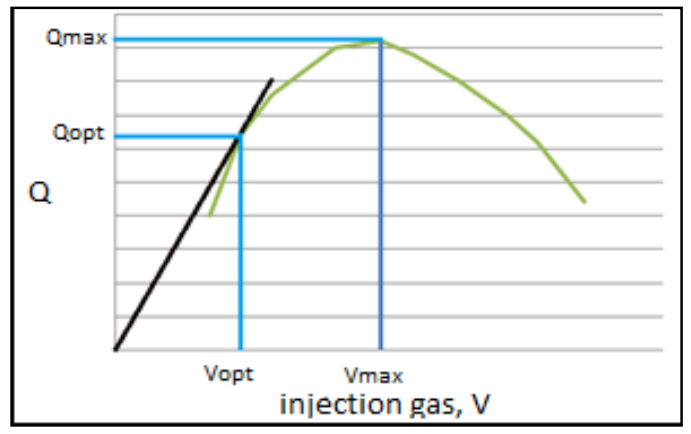

Figure 1. The effect of injection gas to production rate.

\subsection{Survey method}

Basically, the survey method presented here is based on the change of production rate versus volume of injection gas.

Survey procedures:

- Reduced injection gas volume small enough so that the well still working stability, write down injection gas volume $\left(\mathrm{V}_{\mathrm{k} 1}\right)$, injection gas pressure $\left(\mathrm{P}_{\mathrm{k} 1}\right)$ and production rate (QL1).

- Increase the amount of injection gas to about $25 \%$, write down injection gas volume, pressure and production rate when the well working stability. Continue to increase the amount of injection gas by
$25 \%$ of each time and write down those parameters until the production rate decrease.

- Draw the relationships of the injection gas rate $\mathrm{R}=$ $f\left(V_{k}\right)$, the injection gas pressure $P_{k}=f\left(V_{k}\right)$, the production rate $\mathrm{Q}_{\mathrm{L}}=\mathrm{f}\left(\mathrm{V}_{\mathrm{k}}\right)$ and injection gas volume V. (Fig. 2)

The more volume of injection gas, the more production rate we have because of the decrease of fluid density in tubing. But, this only increased to $\mathrm{Q}_{\max }$ value, after that if volume of injection gas continues increasing the production rate will reduce because of slipping between injection gas and oil.

As shown in Fig.2, we can see point 1 at optimal mode (the curve $Q_{L}=f\left(V_{k}\right)$ corresponding to point 2 the minimum injection rate (the curve $\mathrm{R}=\mathrm{f}\left(\mathrm{V}_{\mathrm{k}}\right)$. This means that at this point the cost for injection gas volume is smallest. This is the optimal mode is determined from the perspective of energy.

The maximum production rate of each well can be done at point 3 . The operation mode of a well between optimal mode (point 1) and maximum mode (point 3 ).

$\mathrm{P}_{\mathrm{K}} \mathrm{R} \mathrm{Q}_{\mathrm{L}}$

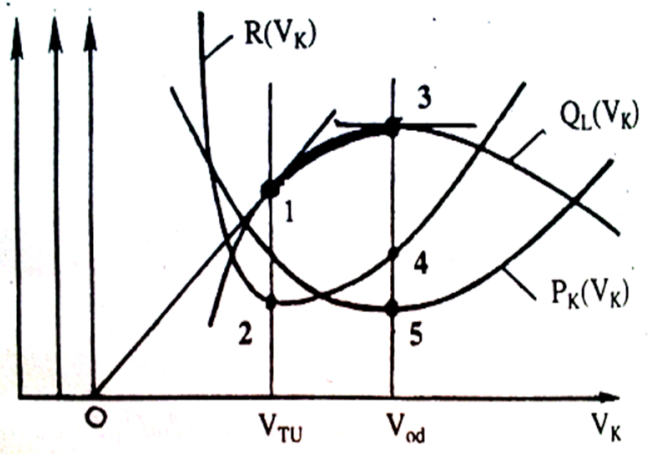

Figure 2. The relationships between injection rate, injection pressure, and production rate versus injection volume

\subsection{The operation equation of each well}

The form of the production rate of each well:

$$
Q=A \cdot V^{2}+B \cdot V+C
$$

(1)

with:

$$
\begin{array}{ll}
\text { - } & \text { Q: production rate }\left(\mathrm{m}^{3} / \mathrm{d}\right) \\
\text { - } & \text { V: injection gas rate }\left(\mathrm{m}^{3} / \mathrm{d}\right) \\
\text { - } & \text { A, B, C: the parameters }
\end{array}
$$


From the survey values and equation (1), we have:

$$
\left\{\begin{array}{l}
Q_{1}=A \cdot V_{1}^{2}+B \cdot V_{1}+C \\
Q_{2}=A \cdot V_{2}^{2}+B \cdot V_{2}+C \\
Q_{3}=A \cdot V_{3}^{2}+B \cdot V_{3}+C
\end{array}\right.
$$

We get A, B, C from the solution of equation system (2).

\subsection{Apply Mathematical Programming to optimizing} gas-lift production method

As shown above, we will define the objective function and constraints and find out the value of injection gas volume to objective function reach the optimal one.

Assume that, we have a group of wells (include $n$ wells). Vi is the injection gas volume of the well $\mathrm{i}(\mathrm{i}=$ $1,2, \ldots, n)$ and $Q_{i}=A \cdot\left(V_{i}\right)^{2}+B \cdot V_{i}+C$ is the operation of well $\mathrm{i}$. VT is the total available volume of injection gas for group of wells.

From the survey method show in item 3 , we will find out the $\mathrm{V}_{\mathrm{i}(\mathrm{opt})}$ and $\mathrm{V}_{\mathrm{i}(\max )}$ of well $\mathrm{i}$. The problem now become:

Objective function:

$$
Q=\sum Q_{i} \rightarrow \max
$$

Constraints:

$$
\left\{\begin{array}{c}
\sum V_{i} \leq V_{T} \\
V_{i(\text { opt })} \leq V_{i} \leq V_{i(\text { critical })}
\end{array}\right.
$$

\section{3. ĐẠI HÙNG FIELD CASE STUDY}

Optimization using mathematical programming method for group of 4 wells in Dai Hung Field, DH-4X, DH-8P, DH-9P, DH-10P with given data in table 1 and

\begin{tabular}{|c|c|c|c|c|c|}
\hline $\begin{array}{l}\text { Well } \\
\text { Name }\end{array}$ & $\begin{array}{c}\text { Volume of } \\
\text { injection gas } \\
\left(\times 10^{3} \mathrm{~m}^{3} / \text { day }\right)\end{array}$ & $\begin{array}{c}\text { Production } \\
\text { Rate } \\
\left(\mathrm{m}^{3} / \text { day }\right)\end{array}$ & $\begin{array}{c}\text { Water } \\
\text { Cut } \\
(\%)\end{array}$ & $\begin{array}{l}\text { Oil density } \\
\left(\mathrm{kg} / \mathrm{m}^{3}\right)\end{array}$ & $\begin{array}{c}\text { Oil rate } \\
\left(\mathrm{m}^{3} / \mathrm{day}\right)\end{array}$ \\
\hline \multirow{6}{*}{ DH- $4 \mathrm{X}$} & 5 & 20 & \multirow{6}{*}{20} & \multirow{6}{*}{780} & 12,48 \\
\hline & 8 & 32 & & & 19,97 \\
\hline & 10 & 38 & & & 23,71 \\
\hline & 14 & 45 & & & 28,08 \\
\hline & 17 & 46 & & & 28,70 \\
\hline & 20 & 44 & & & 27,46 \\
\hline \multirow{6}{*}{ DH-8P } & 9 & 18 & \multirow{6}{*}{30} & \multirow{6}{*}{780} & 9,83 \\
\hline & 12 & 26 & & & 14,20 \\
\hline & 15 & 32 & & & 17,47 \\
\hline & 20 & 40 & & & 21,84 \\
\hline & 25 & 42 & & & 22,93 \\
\hline & 32 & 39 & & & 21,29 \\
\hline \multirow{6}{*}{ DH-9P } & 12 & 22 & \multirow{6}{*}{30} & \multirow{6}{*}{780} & 12,01 \\
\hline & 23 & 48 & & & 26,21 \\
\hline & 30 & 55 & & & 30,03 \\
\hline & 35 & 56 & & & 30,58 \\
\hline & 40 & 53 & & & 28,94 \\
\hline & 45 & 46 & & & 25,12 \\
\hline \multirow{6}{*}{ DH-10P } & 15 & 15 & \multirow{6}{*}{20} & \multirow{6}{*}{780} & 9,36 \\
\hline & 35 & 50 & & & 31,2 \\
\hline & 50 & 65 & & & 40,56 \\
\hline & 65 & 70 & & & 43,68 \\
\hline & 80 & 66 & & & 41,18 \\
\hline & 95 & 52 & & & 32,45 \\
\hline
\end{tabular}
2 below:

Table 1. The situation before optimizing

\begin{tabular}{|l|c|c|c|c|c|}
\hline Well Name & $\begin{array}{c}\text { Volume of } \\
\text { injection gas } \\
\left(\mathrm{x} 10^{3}\right. \\
\left.\mathrm{m}^{3} / \mathrm{day}\right)\end{array}$ & $\begin{array}{c}\text { Production } \\
\text { Rate } \\
\left(\mathrm{m}^{3} / \mathrm{day}\right)\end{array}$ & $\begin{array}{c}\text { Water } \\
\text { Cut }(\%)\end{array}$ & $\begin{array}{c}\text { Oil } \\
\text { density } \\
\left(\mathrm{kg} / \mathrm{m}^{3}\right)\end{array}$ & $\begin{array}{c}\text { Oil } \\
\text { rate } \\
\left(\mathrm{m}^{3} / \text { day }\right)\end{array}$ \\
\hline DH-4X & 8 & 32 & 20 & 780 & 19,97 \\
\hline DH-8P & 15 & 32 & 30 & 780 & 17,47 \\
\hline DH-9P & 45 & 46 & 30 & 780 & 25,12 \\
\hline DH-10P & 35 & 50 & 20 & 780 & 31,2 \\
\hline Total & 103 & 160 & & & 93,76 \\
\hline
\end{tabular}

Table 2. The result from gas-lift well survey

3.1 Optimization for each of gas-lift well in Dai Hung Field

From table 2, and use eq. (1) and (2) we find out the $\mathrm{Q}_{\text {opt }}$ and $\mathrm{V}_{\text {opt. }}$. From the peak of the curve $\mathrm{Q}(\mathrm{V})$ we also have $Q_{\max }$ and $V_{\max }$. The optimal operation mode for each well between optimal to maximum mode. The calculation results shown below:

Well DH-4X:

\section{Trang 168}




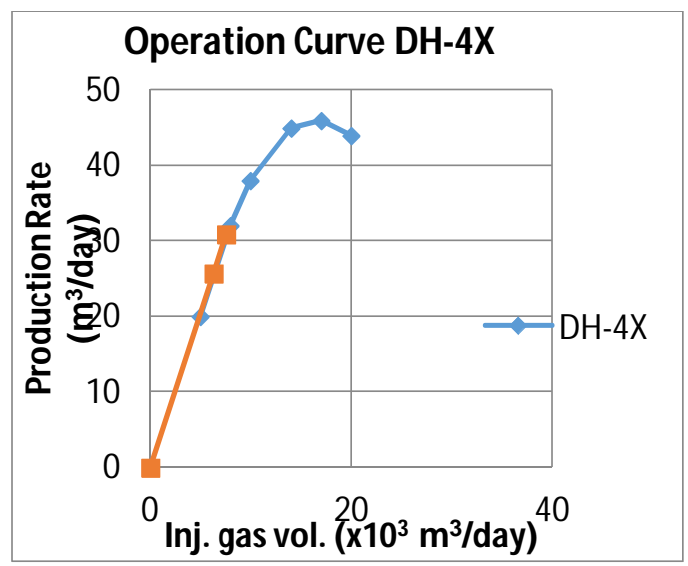

From Operation Curve DH-4X, we get:

$\mathrm{Q}_{\max }=46.5\left(\mathrm{~m}^{3} /\right.$ day $)$ and $\mathrm{V}_{\text {critical }}=16.5 \times 10^{3}\left(\mathrm{~m}^{3} /\right.$ day $)$

$\mathrm{Q}_{\mathrm{opt}}=25.74\left(\mathrm{~m}^{3} /\right.$ day $)$ and $\mathrm{V}_{\mathrm{opt}}=6.3 \times 10^{3}\left(\mathrm{~m}^{3} /\right.$ day $)$

Well DH-8P:

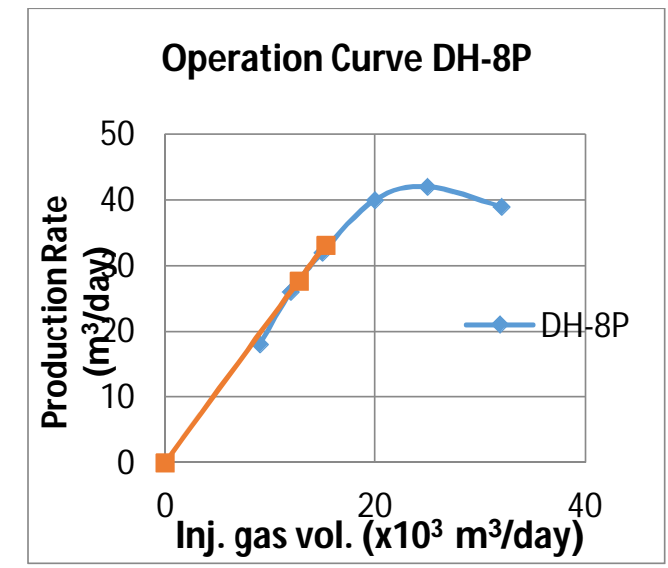

From Operation Curve DH-8P, we get: $\mathrm{Q}_{\max }=38.3\left(\mathrm{~m}^{3} /\right.$ day $)$ and $\mathrm{V}_{\text {critical }}=22.5 \times 10^{3}\left(\mathrm{~m}^{3} /\right.$ day $)$ $\mathrm{Q}_{\text {opt }}=27.64\left(\mathrm{~m}^{3} /\right.$ day $)$ and $\mathrm{V}_{\text {opt }}=12.7 \times 10^{3}\left(\mathrm{~m}^{3} /\right.$ day $)$

Well DH-9P:

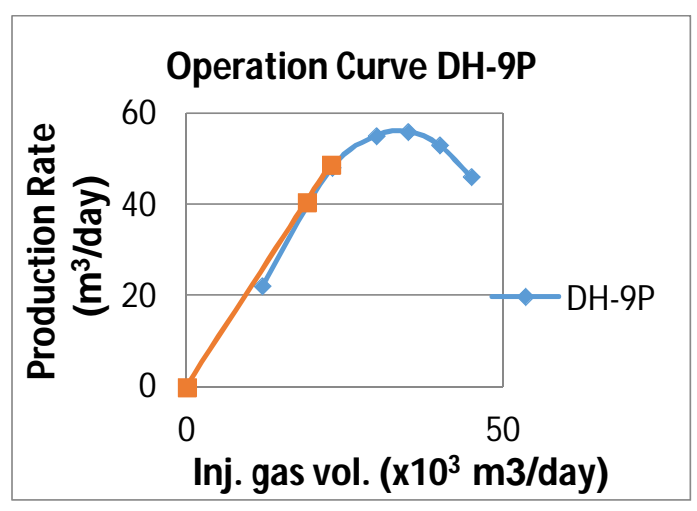

From Operation Curve DH-9P, we get:

$\mathrm{Q}_{\max }=55.7\left(\mathrm{~m}^{3} /\right.$ day $)$ and $\mathrm{V}_{\text {critical }}=33 \times 10^{3}\left(\mathrm{~m}^{3} /\right.$ day $)$ $\mathrm{Q}_{\mathrm{opt}}=40.61\left(\mathrm{~m}^{3} /\right.$ day $)$ and $\mathrm{V}_{\mathrm{opt}}=19 \times 10^{3}\left(\mathrm{~m}^{3} /\right.$ day $)$
Well DH-10P:

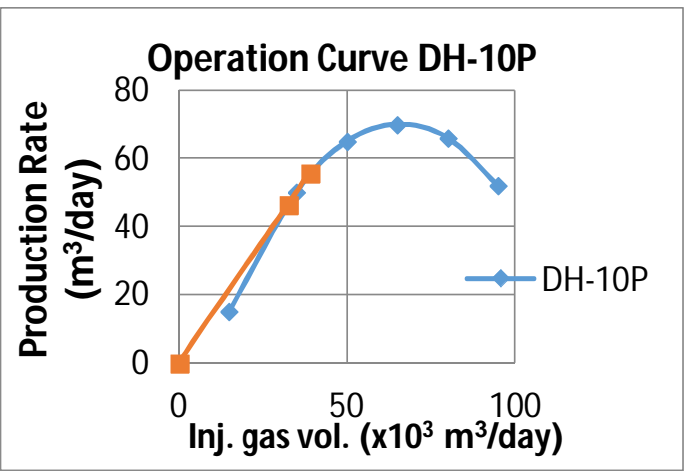

From Operation Curve DH-10P, we get:

$\mathrm{Q}_{\max }=70.4\left(\mathrm{~m}^{3} /\right.$ day $)$ and $\mathrm{V}_{\text {critical }}=65.8 \times 10^{3}\left(\mathrm{~m}^{3} /\right.$ day $)$

$\mathrm{Q}_{\mathrm{opt}}=46.24\left(\mathrm{~m}^{3} /\right.$ day $)$ and $\mathrm{V}_{\mathrm{opt}}=32.4 \times 10^{3}\left(\mathrm{~m}^{3} /\right.$ day $)$

3.2 Simultaneous optimization for Group of 4 wells above

From data from table 2, using eq. (1) and (2) we have the operation equation for each well shown below:

- $\mathrm{DH}-4 \mathrm{X}: \mathrm{Q}=-0.2 \mathrm{~V}^{2}+6.6 \mathrm{~V}-8$

- DH-8P: $\mathrm{Q}=-0.111 \mathrm{~V}^{2}+5 . \mathrm{V}-18$

- DH-9P: $\mathrm{Q}=-0.076 \mathrm{~V}^{2}+0.015 \mathrm{~V}-27.273$

- DH-10P: $\mathrm{Q}=0.021 \mathrm{~V}^{2}+2.821 \mathrm{~V}-22.5$

Apply mathematical programming for this problem: Obj. function:

$\mathrm{Q}=\mathrm{QDH}_{\mathrm{DH}}+\mathrm{Q}_{\mathrm{DH}-8 \mathrm{P}}+\mathrm{Q}_{\mathrm{DH}-9 \mathrm{P}}+\mathrm{QDH}_{\mathrm{D}-10 \mathrm{P}} \rightarrow \max$

Constraints:

$\mathrm{V}_{\mathrm{DH}-4 \mathrm{X}}+\mathrm{V}_{\mathrm{DH}-8 \mathrm{P}}+\mathrm{V}_{\mathrm{DH}-9 \mathrm{P}}+\mathrm{V}_{\mathrm{DH}-10 \mathrm{P}} \leq 130$

and $\quad V_{\mathrm{i}(\text { opt })} \leq \mathrm{V}_{\mathrm{i}} \leq \mathrm{V}_{\mathrm{i} \text { (critical })}$

The result of solution we have:

$$
\begin{aligned}
& V_{\text {DH-4X }}=14.14 ; V_{\text {DH-8P }}=18.24 ; \\
& V_{\text {DH-9P }}=26.86 ; V_{\text {DH-10P }}=43.76
\end{aligned}
$$

Calculate the production rate for each well after optimization by this equation:

$$
Q=\left(A \cdot V^{2}+B \cdot V+C\right) \cdot(1-n) \cdot \rho
$$

With: - n: water cut; - $\rho$ : oil density 
- Table below show us the detail of calculation results:

Oil production rate before and after optimization

Table 3- The results of calculation after optimization for the group wells

\begin{tabular}{|c|c|c|c|}
\hline Well Name & $\begin{array}{c}\text { Injection gas } \\
\text { volume each } \\
\text { well }\left(\mathrm{x} 10^{3}\right. \\
\left.\mathrm{m}^{3} / \mathrm{day}\right)\end{array}$ & $\begin{array}{c}\text { Production rate } \\
\text { after } \\
\text { optimization } \\
\left(\mathrm{m}^{3} / \text { day }\right)\end{array}$ & $\begin{array}{c}\text { Oil Production } \\
\text { Rate after } \\
\text { optimization } \\
\text { (ton/day) }\end{array}$ \\
\hline DH-4X & 14,14 & 45,33 & 28,29 \\
\hline DH-8P & 18,24 & 36,24 & 19,79 \\
\hline DH-9P & 26,86 & 52,78 & 28,82 \\
\hline DH-10P & 43,76 & 59,93 & 37,4 \\
\hline Total & 103 & 194,28 & 114,29 \\
\hline
\end{tabular}

After optimization of distribution the amount injection gas for the group wells we get the production rate increase by $34.28 \mathrm{~m}^{3} /$ day, oil-production increase by 20.53 ton/day. The comparison of production rate, volume of injection gas before and after optimization shown by the charts below:
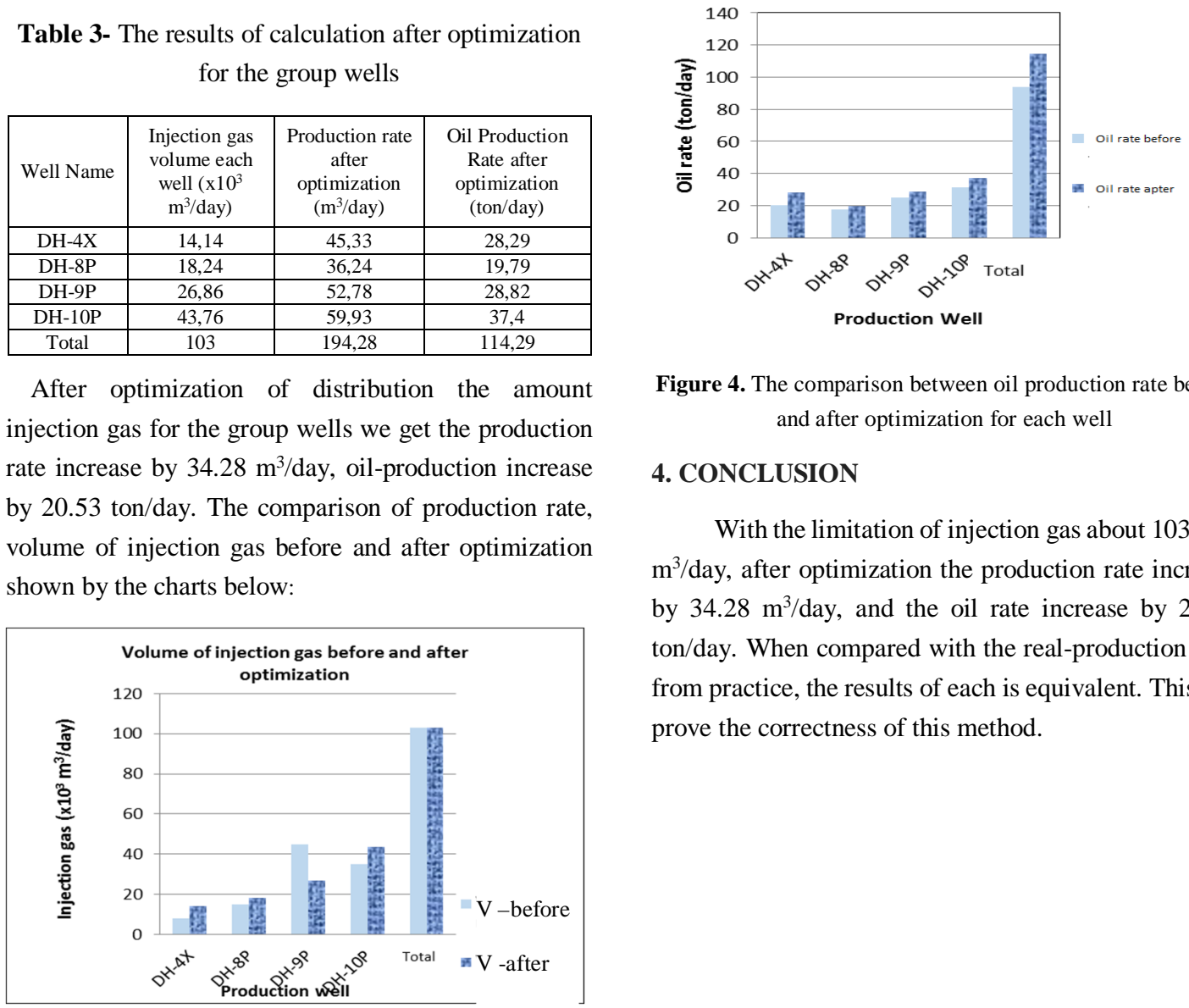

Figure 4. The comparison between oil production rate before and after optimization for each well

\section{CONCLUSION}

With the limitation of injection gas about $103 \times 10^{3}$ $\mathrm{m}^{3} /$ day, after optimization the production rate increase by $34.28 \mathrm{~m}^{3} / \mathrm{day}$, and the oil rate increase by 20.53 ton/day. When compared with the real-production data from practice, the results of each is equivalent. This can prove the correctness of this method.

Figure 3. The comparison between volume of injection gas before and after optimization for each well

\section{Trang $\mathbf{7 0}$}




\section{Ưng dụng phương pháp quy hoạch toán học tối ưu hóa lượng khí nén bơm ép cho mỏ Đại Hùng, bồn trũng Nam Côn Sơn, ngoài khơi Việt Nam}

- Phùng Đại Khánh

- Lê Thanh Liêm

- Hoàng Trọng Quang

Trường Đại học Bách khoa, ĐHQG-HCM

\section{TÓM TÁT:}

Trong khai thác dầu bằng phương pháp gaslift, do lượng khí nén thường là có hạn, nên vấn đề tối ưu hóa việc phân bổ lượng khí nén cho các giếng trong một mỏ luôn được quan tâm. Đã có một số phương pháp tối ưu hóa cho nhóm giếng khai thác gaslift ở Việt nam, nhưng chủ yếu là sử

dụng phương pháp giải tích toán học với lời giải là tìm cực trị của hàm đa biến. Bài báo này sẽ đề cập đến việc áp dụng một phương pháp tối ưu hóa cho nhóm giếng khai thác gaslift - phương pháp Quy hoạch toán học - ứng dụng cho mỏ Đại Hùng bồn trũng Nam Côn Sơn Việt Nam.

Từ khóa: Quy hoạch toán học, tối ưu hóa, gas-lift, khí bơm ép.

\section{TÀI LIỆU THAM KHẢO}

[1]. Lê Phước Hảo, Cơ sở khoan và khai thác dầu khí. Chapter 10. Vietnam National University Publisher in HCMc, 2002.

[2]. Phùng Đình Thực, Dương Danh Lam, Lê Bá Tuấn, Nguyễn Văn Cảnh, Công nghệ và kỹ thuật khai

thác dầu khí. Chapter 10. Education Publisher, 1999.

[3]. Nguyễn Hải Thanh, Tối ưu hóa - Giáo trình cho ngành tin học và Công nghệ thông tin, Đại học Bách khoa - Hà nội, 2006 